International Journal of Instruction e-ISSN: 1308-1470 • www.e-iji.net

Article submission code: 20190716112137

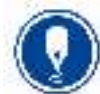

January $2021 \bullet$ Vol.14, No.1

p-ISSN: 1694-609X

pp. 379-394

Received: $16 / 07 / 2019$

Revision: 26/06/2020
Accepted: 18/07/2020

OnlineFirst:24/10/2020

\title{
Knowledge, Education and Use of Teaching Styles in Physical Education
}

\author{
María Fernández \\ Universidad Pontificia de Comillas, Spain,mfrivas@ comillas.edu \\ María Espada \\ Universidad politécnica de Madrid, Spain, maria.espada@upm.es
}

1

Teaching styles in physical education are important for achieving teaching objectives. Therefore, the goal of this research was to analyse the knowledge, education and use of physical education teachers about these styles based on their teaching degree. The size of the sample was determined using the formula for finite populations physical, being a sample of 455 randomly chosen which are physical education teachers in primary and secondary schools in the Community of Madrid. An inferential analysis was carried out using correlation coefficients such as ANOVA and Welch. The results show significant differences in the use of different teaching styles regarding degree, such as command style ( $\mathrm{p}=.011)$, task assignment $(\mathrm{p}=.033)$, guided discovery $(\mathrm{p}=.000)$, solving problem $(\mathrm{p}=.000)$ and free exploration ( $\mathrm{p}=.000)$. One of the most significant conclusions reached, pointed out that the command style is the style most commonly used by graduate teachers in Physical Activity and Sport Sciences, while teachers with degree in Physical Education or teachers with both degrees use more the others styles. It is important to know what teaching styles are used by physical education teachers and so they increase their knowledge about creative teaching styles if it was necessary.

Keywords: physical education, teaching styles, productive styles, reproductive styles, degree

\section{INTRODUCTION}

The methodology which teachers use is essential for improving students' learning, and thus the teaching styles used in physical educational are vital for achieving the objectives of the activity.

For this reason, it is necessary more researches about pedagogical models which resolve different disadvantages of both models. Thus, Khalaf (2018) carried out a research aim to know advantages and disadvantages of traditional and inquired-based learning, and he observed that both pedagogical models have disadvantages.

In the same way, the teaching styles are important to improve the teaching-learning process, and for this reason, they should be reviewed too.

Citation: Fernández, M. \& Espada, M. (2021). Knowledge, Education and Use of Teaching Styles in Physical Education. International Journal of Instruction, 14(1), 379-394. https://doi.org/10.29333/iji.2021.14122a 
In the first place, it should know that the expression "teaching styles" was created to establish the relationship between teacher and students, improving the educative experience and allowing students to gain different useful skills for their later life experience (Montero, 1995; Escudero, 2005).

Teaching styles make it possible to show the interaction between teacher and student when they make decisions in the teaching-learning process and also, what roles the teacher and student play in this process (Mosston, 1978). Thus, there are research which study the different models about teaching style throughout education (Byra, 2000; Goldberger, Ashworth and Byra, 2012). In them, it is possible to observe two categories of teaching styles to carry out the physical education classes, reproductive and productive styles. Goodyear and Dudley (2015), speak about productive styles, considering that "teacher must play an active role in the classroom and should be considered much more than a "guide on the side".

The teaching styles used, intervene in the teaching act, and are more efficient when teachers are able to use different styles, and mix them in their physical education class (Delgado, 1996).

Mosston developed the first proposal on teaching styles in 1966 with a book called "Teaching Physical Education. From command to discovery" (during a period of controversy) in which he included the Spectrum of teaching styles. This spectrum claims that teaching qualities depend on the number of decisions made by the students. The teaching styles in this period were: the command style, the task-based style, small groups, individual programmes, guided discovery, problem solving and creativity (Mosston, 1978).

Later, in 1986 Mosston changed his proposal and published another book where he reformed the teaching styles from the previous period (during a time with no controversy). In this period, teaching styles were intended to respond to the objective proposed. So, the difference between reproductive or productive styles depended on the decisions made by the students (Mosston and Ashworth, 2002). Thus, the reproductive styles are: Command style (A), Practice (B), Reciprocal teaching (C), Self-evaluation (D) and Inclusion (E). The productive styles are: Guided discovery (F), Problem solving (Divergent discovery) (G), Individualised programme (H), Learner-Initiated (I) and Self-teaching (J).

After that, Delgado (1991) taking Mosston's proposal as a reference, changed some teaching styles and added new ones, grouping them together in different families (Traditional styles: Command style, Modification of command style and Task assignment; styles which enable participation: Reciprocal teaching, Small groups and Microteaching; styles which promote individualisation: Individualisation by groups, Modular teaching, Programmed teaching and Individualised programmes; styles which involve the students cognitively: Guided discovery and Problem solving; styles which favour socialisation: Social style; styles which favour creativity: Free exploration

It exist different research carried out over the years on teaching styles. Thus, it is necessary to do a review about these research to prove our investigation after that. 
Table 1

Overview of research on teaching styles

\begin{tabular}{|c|c|c|c|c|}
\hline Author/s & Year & Country & Author's proposal & Results \\
\hline Boyce & 1992 & United States & $\begin{array}{l}\text { Mosston and } \\
\text { Ashworth (2002). }\end{array}$ & $\begin{array}{l}\text { The most significant teaching styles are the } \\
\text { command style and task assignment. }\end{array}$ \\
\hline Delgado et al. & 1996 & Spain & Delgado (1991) & $\begin{array}{l}\text { The most accepted teaching styles are } \\
\text { social, individual, creative and cognitive } \\
\text { styles }\end{array}$ \\
\hline Delgado & 1998 & Spain & Delgado (1991) & $\begin{array}{l}\text { The most accepted teaching styles are } \\
\text { social, individual, creative and cognitive } \\
\text { styles } \\
\text { The most rejected teaching styles are } \\
\text { traditional styles }\end{array}$ \\
\hline Byra and Jenkins & 1998 & United States & $\begin{array}{l}\text { Mosston and } \\
\text { Ashworth (2002). }\end{array}$ & $\begin{array}{l}\text { They wanted to know which decisions are } \\
\text { taken by students with the inclusion style. } \\
\text { So, the research showed that students } \\
\text { decide the work level. }\end{array}$ \\
\hline $\begin{array}{l}\text { Curtner-Smith et } \\
\text { al. }\end{array}$ & 2001 & England & $\begin{array}{l}\text { Mosston and } \\
\text { Ashworth (2002). }\end{array}$ & $\begin{array}{l}\text { The results showed that the most used } \\
\text { teaching style was the practice style. }\end{array}$ \\
\hline $\begin{array}{l}\text { Morgan, } \\
\text { Kingston, and } \\
\text { Sproule }\end{array}$ & 2005 & $\begin{array}{l}\text { United } \\
\text { Kingdom }\end{array}$ & $\begin{array}{l}\text { Mosston and } \\
\text { Ashworth (2002). }\end{array}$ & $\begin{array}{l}\text { The teaching styles that most influence } \\
\text { motivation and class environment are } \\
\text { guided discovery and reciprocal teaching. }\end{array}$ \\
\hline Cothran et al. & 2005 & Several & $\begin{array}{l}\text { Mosston and } \\
\text { Ashworth (2002). }\end{array}$ & $\begin{array}{l}\text { There are significant differences. Although } \\
\text { all teachers used several teaching styles in a } \\
\text { physical education class. }\end{array}$ \\
\hline Salvara et al. & 2006 & Greece & $\begin{array}{l}\text { Mosston and } \\
\text { Ashworth (2002). }\end{array}$ & $\begin{array}{l}\text { There is positive motivation through guided } \\
\text { discovery, the divergent style, } \\
\text { individualised programmes, reciprocal } \\
\text { teaching and self-evaluation }\end{array}$ \\
\hline Derri and Pachta & 2007 & Greece & $\begin{array}{l}\text { Mosston and } \\
\text { Ashworth (2002). }\end{array}$ & $\begin{array}{l}\text { There were no significant differences. It is } \\
\text { possible to observe that the command style } \\
\text { allows better learning, although guided } \\
\text { discovery promotes knowledge acquisition }\end{array}$ \\
\hline $\begin{array}{l}\text { Patmanoglou et } \\
\text { al. }\end{array}$ & 2008 & Greece & $\begin{array}{l}\text { Mosston and } \\
\text { Ashworth (2002). }\end{array}$ & $\begin{array}{l}\text { The self-evaluation style allows a more } \\
\text { effective learning and creates a positive } \\
\text { attitude to sport in the students }\end{array}$ \\
\hline Zeng et al. & 2009 & United States & $\begin{array}{l}\text { Mosston and } \\
\text { Ashworth (2002). }\end{array}$ & $\begin{array}{l}\text { The practice style produced better result in } \\
\text { men, while inclusion and reciprocal styles } \\
\text { were more effective in women. }\end{array}$ \\
\hline $\begin{array}{l}\text { Jaakkola and } \\
\text { Watt }\end{array}$ & 2011 & Finland & $\begin{array}{l}\text { Mosston and } \\
\text { Ashworth (2002). }\end{array}$ & $\begin{array}{l}\text { The most used teaching styles were the } \\
\text { command style and practice style. } \\
\text { Practice and divergent styles were the ones } \\
\text { that most favoured learning. } \\
\text { Practice, divergent and inclusion styles are } \\
\text { the most accepted by students. } \\
\text { Finally, practice and inclusion are the most } \\
\text { motivating for students. }\end{array}$ \\
\hline $\begin{array}{l}\text { Koloveloni, } \\
\text { Goudas and } \\
\text { Gerodimos. }\end{array}$ & 2011 & Greece & $\begin{array}{l}\text { Mosston and } \\
\text { Ashworth (2002). }\end{array}$ & $\begin{array}{l}\text { The reciprocal and self-evaluation styles } \\
\text { were the most effective to improve } \\
\text { academic performance. }\end{array}$ \\
\hline $\begin{array}{l}\text { Sánchez, Byra } \\
\text { and Wallhead }\end{array}$ & 2012 & United State & $\begin{array}{l}\text { Mosston and } \\
\text { Ashworth (2002). }\end{array}$ & $\begin{array}{l}\text { The inclusion style allows more physical } \\
\text { and cognitive involvement. According to } \\
\text { social interaction, there are no significant } \\
\text { differences among teaching styles. }\end{array}$ \\
\hline
\end{tabular}

International Journal of Instruction, January $2021 \bullet$ Vol.14, No.1 


\begin{tabular}{|c|c|c|c|c|}
\hline Author/s & Year & Country & Author's proposal & Results \\
\hline & & & & Students prefer the inclusion style. \\
\hline Isaza and Henao & 2012 & Colombia & Delgado (1991) & $\begin{array}{l}\text { Individualised, participatory, creative and } \\
\text { social styles are more accepted than } \\
\text { traditional styles. }\end{array}$ \\
\hline $\begin{array}{l}\text { Hewitt and } \\
\text { Kenneth }\end{array}$ & 2013 & Australia & Mosston (1978). & $\begin{array}{l}\text { The practice style is the most used to teach } \\
\text { tennis. In contrast, the least used is the } \\
\text { command style }\end{array}$ \\
\hline $\begin{array}{l}\text { Amado, } \\
\text { Sanchez-Miguel, } \\
\text { Gonzalez-Ponce, } \\
\text { Pulido-Gonzalez } \\
\text { and del Villar }\end{array}$ & 2016 & Spain & Delgado (1991) & $\begin{array}{l}\text { It is important to use reproductive and } \\
\text { productive styles for a comprehensive } \\
\text { education }\end{array}$ \\
\hline $\begin{array}{l}\text { Merino-Barreto, } \\
\text { Valero- } \\
\text { Valenzuela, and } \\
\text { Moreno-Murcia }\end{array}$ & 2017 & Spain & Delgado (1991) & $\begin{array}{l}\text { Teacher under the ages of } 30 \text { prefer creative } \\
\text { and social styles and cognitives styles, but it } \\
\text { changes to the extent teachers draw on age }\end{array}$ \\
\hline $\begin{array}{l}\text { Heras- } \\
\text { Fernández, } \\
\text { Espada, Cuellar- } \\
\text { Moreno }\end{array}$ & 2018 & Spain & $\begin{array}{l}\text { Mosston and } \\
\text { Ashworth (2002) }\end{array}$ & $\begin{array}{l}\text { The use of problem solving favour the } \\
\text { participation cognitive, physical and } \\
\text { emotional compared with command styles }\end{array}$ \\
\hline $\begin{array}{l}\text { Cuellar-Moreno } \\
\text { and Caballero- } \\
\text { Julio }\end{array}$ & 2019 & Spain & $\begin{array}{l}\text { Mosston and } \\
\text { Ashworth (2002) }\end{array}$ & $\begin{array}{l}\text { Comparison between problem solving and } \\
\text { command styles in dace. It is show that } \\
\text { problem solving in more motivation for } \\
\text { students and favour cognition in them }\end{array}$ \\
\hline $\begin{array}{l}\text { SueSee, } \\
\text { Edwards, Pill } \\
\text { and Cuddihy }\end{array}$ & 2019 & $\begin{array}{l}\text { Queensland } \\
\text { (Australia) }\end{array}$ & $\begin{array}{l}\text { Mosston and } \\
\text { Ashworth (2002) }\end{array}$ & $\begin{array}{l}\text { Senior physical education teachers use } \\
\text { several teaching styles in their classes }\end{array}$ \\
\hline
\end{tabular}

\section{Objectives}

- To analyse the level of knowledge of physical education teachers regarding their teaching degree.

- To find out if they had followed courses on teaching styles in the previous year and if there was a relation with their teaching degree.

- To ascertain the use of teaching styles by the physical education teachers regarding their teaching degree

\section{METHOD}

A quantitative, descriptive and non-experimental methodology was used for this research, as it required an objective process through statistical analysis (Anguera 1992; González Tirados, 2009).

\section{Participants}

This research used a sample of 455 teachers of whom $280(61.5 \%)$ belonged to the primary stage and $175(38.5 \%)$ belonged to the secondary stage. In addition, there were teachers who were graduates in physical activity and sport sciences $(21.1 \%)$, graduates in physical education (47.7\%) and teachers with both degrees (31.2\%); 70.8\% were men and $29.2 \%$ women. 
To calculate the sample universe, the number of schools in the Autonomous Region of Madrid was determined from the different lists in this region, as it is impossible to know the exact number of teachers who work in these schools. The lists used are of the primary and secondary schools in the Region detailed in the regional schools guide (Autonomous Region of Madrid, 2014) and the list of municipalities and population in the same region for the year 2013 (Institute of Statistics from the Autonomous Region of Madrid, 2013), in total 1659 schools.

The size of the sample was determined using the formula for finite populations (Cea D'Ancona, 2004; Bravo Sierra, 2001), where the worst case is assumed regarding the population variance, with "P" and "Q" being equal, with a value of 50\% each. The value of confidence was $95.5 \%$ with - 2 sigmas and +2 sigmas for a normal distribution, and a margin of error of $\pm 4.75 \%$ for the established sample, obtaining a sample of 455 units in the population.

The sampling design was probabilistic, random cluster and stratified to achieve a more objective selection. The stratification consisted, in the first place, in dividing the population into municipalities, in the second place, into schools, randomly selecting the participating schools, and finally, choosing the teachers to be interviewed also randomly (a maximum of two teachers per school). This was done using the table of random numbers proposed by Rodríguez Osuna (2002).

Thus the collection of data was always proportional in the established criteria to municipal population size and geographic area, making the distribution according to the defined territorial areas of the total universe, taking into account the inhabitants per municipality, so more surveys were carried out in strata with more inhabitants (Cea D'Ancona, 2001).

\section{Measure}

The instrument used in this case is a questionnaire which was used, designed and validated by Guedea (2010). This questionnaire is called the Questionnaire for the analysis of teaching styles used in Physical Education. Several Ph.D.s from Spanish Universities reviewed and validated it, finding a Cronbach alpha coefficient $=.702$.

The questionnaire has several dimensions. The dimension use in this research names importance of teaching styles in Physical Education classes and it include items about knowledge of teaching styles, if teachers have done course about them last year and used some of them. In this case, the measurement analysed the importance of teaching styles in Physical Education classes. The items used are eight, and they are closed, in the form of a scale from 1 to 5 .

The items analyse in this research are:

1. Knowledge about teaching styles when physical education teachers start to work

2. Did you have courses last year?

3. Do you constantly use the command style? 
4. Do you constantly use the task assignment style?

5. Do you constantly use the reciprocal teaching style?

6. Do you constantly use the guided discovered style?

7. Do you constantly use the problem solving style?

8. Do you constantly use the creative style?

\section{Procedure}

The first phase involved place location and contact with the schools and teachers selected for the study, following the guidelines established in the sampling design. Then, the standardised interviews were carried out with the questionnaire and the information obtained was collected and recorded.

It was a cross-sectional study (Sierra Bravo, 2001), in this case it took place in the 20142015 academic year during school hours, since it was aimed at physical education teachers in formal education. The interviews were carried out by a single interviewer, because this procedure is more effective and more rigorous although it involved more work (Cea D'Ancona, 2001).

\section{Statistical Analysis}

The statistical analysis involved, on the one hand, a descriptive analysis through frequencies, and on the other hand, an inferential analysis through correlation coefficients (Levene, ANOVA and Welch and the post-hoc test) all using the statistical program SPSS $\AA$, Version 20.

\section{FINDINGS}

The greatest difference can be seen in the first item about if teachers knew the teaching styles when they started to give classes, being higher in those respondents who have both degrees $(\mathrm{M}=8.29$; $\mathrm{DT}=1.65)$.

Later, the inferential analysis through different correlation coefficients was conducted to analyse the items about knowledge, education and use of teaching styles.

The Levene test was carried out (table 2) showing significant differences of variance in item 1 about if teachers knew the teaching styles when they began to teach $(p=.000)$; item 2 about whether they had had courses about teaching styles $(\mathrm{p}=.000)$; item 4 about whether they constantly used the task assignment style $(\mathrm{p}=.013)$; and item 7 about whether they constantly used the problem solving style $(p=.000)$. 
Table 2

Levene test based on degree.

\begin{tabular}{lllll}
\hline Items & Levene & gl1 & gl2 & Sig. \\
\hline $\begin{array}{l}\text { 1. Knowledge about teaching styles when physical education } \\
\text { teachers start to work }\end{array}$ & 10,868 & 2 & 452 & 0 \\
\hline 2. Did you have courses last year? & 9,685 & 2 & 452 & 0 \\
\hline 3. Do you constantly use the command style? & 2,481 & 2 & 452 & 0,085 \\
\hline 4. Do you constantly use the task assignment style? & 4,408 & 2 & 452 & 0,013 \\
\hline 5. Do you constantly use the reciprocal teaching style? & 2,308 & 2 & 452 & 0,101 \\
\hline 6. Do you constantly use the guided discovered style? & 1,961 & 2 & 452 & 0,142 \\
\hline 7. Do you constantly use the problem solving style? & 15,168 & 2 & 452 & 0 \\
\hline 8. Do you constantly use the creative style? & 0,5 & 2 & 452 & 0,607 \\
\hline
\end{tabular}

Then the Welch test was applied (table 3), where there were significant differences all of items. In item 1, about if teachers knew teaching styles when they started to work $(\mathrm{p}=.002)$; item 2, about whether teachers had had courses about teaching styles $(\mathrm{p}=.007)$; and items 4 and 7 , about whether teachers constantly used the task assignment and the problem solving styles $(\mathrm{p}=.033 ; \mathrm{p}=.000)$.

Table 3

Welch test regarding degree.

\begin{tabular}{lllll}
\hline Itmes & Stadistic & gl1 & gl2 & Sig. \\
\hline $\begin{array}{l}\text { 1. Knowledge about teaching } \\
\text { education teachers start to work }\end{array}$ & 6,191 & 2 & 244 & 0,002 \\
\hline $\begin{array}{l}\text { 2. Did you have courses last year? } \\
\text { 4. Do you constantly use the task assignment style? }\end{array}$ & 5,12 & 2 & 227 & 0,007 \\
\hline 7. Do you constantly use the problem solving style? & 10,373 & 2 & 246 & 0,033 \\
\hline
\end{tabular}

The Games - Howell post-hoc test was used to discover where these differences were (Table 4), and they existed in item 1, about if teachers knew teaching styles when they started to work, because there were significant differences between teachers who have both degrees, who said that they knew teaching styles when they started to work, in comparison with those who are graduates in physical education $(\mathrm{p}=.002)$.

In item 2 about whether teachers had had courses about teaching styles in the previous year, it possible to observe that more teachers who have both degrees had had courses in the previous year compared to graduates in physical education $(\mathrm{p}=.005)$.

Similarly, regarding if teachers constantly used the task assignment style, there were significant differences between teachers who have both degrees and those who are graduates in physical education (item $4 ; \mathrm{p}=.033$ ). Again the teachers who have both 
degrees were the ones who constantly used this style compared to teachers who are graduates in physical education.

Regarding the constant use of the problem solving style, significant differences were revealed between teachers who are graduates in physical education or who have two degrees constantly using the problem solving style compared to teachers who are graduates in physical activity and sport sciences $(\mathrm{p}=.000, \mathrm{p}=.025)$.

Table 4

The Games - Howell post - hoc test regarding degree.

\begin{tabular}{|c|c|c|c|c|c|}
\hline Items & (I) Degree & (J) Degree & $\begin{array}{l}\text { Mean } \\
\text { difference (I-J) }\end{array}$ & $\begin{array}{l}\text { Typical } \\
\text { error }\end{array}$ & Sig. \\
\hline \multirow{6}{*}{$\begin{array}{l}\text { 1. Knowledge about } \\
\text { teaching styles when } \\
\text { physical education } \\
\text { teachers start to } \\
\text { work }\end{array}$} & \multirow[t]{2}{*}{$\begin{array}{l}\text { Graduates in physical } \\
\text { education }\end{array}$} & $\begin{array}{l}\text { Physical activity and } \\
\text { sport sciences } \\
\text { graduates }\end{array}$ & $-0,45$ & 0,21 & 0,075 \\
\hline & & Both degrees &,$- 561 *$ & 0,16 & 0,002 \\
\hline & \multirow{2}{*}{$\begin{array}{l}\text { Physical activity and } \\
\text { sport sciences graduates }\end{array}$} & $\begin{array}{l}\text { Graduates in physical } \\
\text { education }\end{array}$ & 0,449 & 0,21 & 0,075 \\
\hline & & Both degrees & $-0,11$ & 0,18 & 0,811 \\
\hline & \multirow{2}{*}{ Both degrees } & $\begin{array}{l}\text { Graduates in physical } \\
\text { education }\end{array}$ &, $561 *$ & 0,16 & 0,002 \\
\hline & & $\begin{array}{l}\text { Physical activity and } \\
\text { sport sciences } \\
\text { graduates }\end{array}$ & 0,112 & 0,18 & 0,811 \\
\hline \multirow[t]{6}{*}{$\begin{array}{l}\text { 2. Did you have } \\
\text { courses last year? }\end{array}$} & \multirow[t]{2}{*}{$\begin{array}{l}\text { Graduates in physical } \\
\text { education }\end{array}$} & $\begin{array}{l}\text { Physical activity and } \\
\text { sport sciences } \\
\text { graduates }\end{array}$ & -0.465 & 0.342 & 0.365 \\
\hline & & Both degrees & $-.979 *$ & 0.309 & 0.005 \\
\hline & \multirow{2}{*}{$\begin{array}{l}\text { Physical activity and } \\
\text { sport sciences graduates }\end{array}$} & $\begin{array}{l}\text { Graduates in physical } \\
\text { education }\end{array}$ & 0.465 & 0.342 & 0.365 \\
\hline & & Both degrees & -0.514 & 0.391 & 0.389 \\
\hline & \multirow[b]{2}{*}{ Both degrees } & $\begin{array}{l}\text { Graduates in physical } \\
\text { education }\end{array}$ & $.979 *$ & 0.309 & 0.005 \\
\hline & & $\begin{array}{l}\text { Physical activity and } \\
\text { sport sciences } \\
\text { graduates }\end{array}$ & 0.514 & 0.391 & 0.389 \\
\hline \multirow[t]{6}{*}{$\begin{array}{l}\text { 4. Do you constantly } \\
\text { use the task } \\
\text { assignment style? }\end{array}$} & \multirow[t]{2}{*}{$\begin{array}{l}\text { Graduates in physical } \\
\text { education }\end{array}$} & $\begin{array}{l}\text { Physical activity and } \\
\text { sport sciences } \\
\text { graduates }\end{array}$ & -0.377 & 0.213 & 0.184 \\
\hline & & Both degrees & $-.445 *$ & 0.177 & 0.033 \\
\hline & $\begin{array}{l}\text { Physical activity and } \\
\text { sport sciences graduates }\end{array}$ & $\begin{array}{l}\text { Graduates in physical } \\
\text { education }\end{array}$ & 0.377 & 0.213 & 0.184 \\
\hline & & Both degrees & -0.068 & 0.212 & 0.945 \\
\hline & \multirow[b]{2}{*}{ Both degrees } & $\begin{array}{l}\text { Graduates in physical } \\
\text { education }\end{array}$ & $.445^{*}$ & 0.177 & 0.033 \\
\hline & & $\begin{array}{l}\text { Physical activity and } \\
\text { sport sciences } \\
\text { graduates }\end{array}$ & 0.068 & 0.212 & 0.945 \\
\hline 7. Do you constantly & Graduates in physical & Physical activity and & $.637 *$ & 0.242 & 0.025 \\
\hline
\end{tabular}




\begin{tabular}{|c|c|c|c|c|c|}
\hline \multirow[t]{6}{*}{$\begin{array}{l}\text { use the problem } \\
\text { solving style? }\end{array}$} & \multirow[t]{2}{*}{ education } & \multicolumn{4}{|l|}{$\begin{array}{l}\text { sport sciences } \\
\text { graduates }\end{array}$} \\
\hline & & Both degrees & -0.382 & 0.175 & 0.075 \\
\hline & \multirow{2}{*}{$\begin{array}{l}\text { Physical activity and } \\
\text { sport sciences graduates }\end{array}$} & $\begin{array}{l}\text { Graduates in physical } \\
\text { education }\end{array}$ & $-.637 *$ & 0.242 & 0.025 \\
\hline & & Both degrees & $-1.018 *$ & 0.228 & 0 \\
\hline & \multirow[b]{2}{*}{ Both degrees } & $\begin{array}{l}\text { Graduates in physical } \\
\text { education }\end{array}$ & 0.382 & 0.175 & 0.075 \\
\hline & & $\begin{array}{l}\text { Physical activity and } \\
\text { sport sciences } \\
\text { graduates }\end{array}$ & $1.018^{*}$ & 0.228 & 0 \\
\hline
\end{tabular}

* The difference of means is significant at .05 .

An ANOVA test was carried out for items in which there were not significant differences in the Levene test (table 5), nor differences of variance, like in items 3, 5, 6 and 8 , about if teachers constantly used the command style, reciprocal teaching, guided discovery and free exploration styles.

In these cases, the ANOVA test showed significant differences in the items about if teachers constantly used the command style (item $3 ; \mathrm{p}=.011$ ), guided discovery item 6 ; $(\mathrm{p}=.000)$ and free exploration (item 8; $\mathrm{p}=.000)$.

Table 5

ANOVA test regarding degree.

\begin{tabular}{llllll}
\hline Items & & Sum of squares & gl & F & Sig. \\
\hline $\begin{array}{llllll}\text { 3. Do you constantly use the } \\
\text { command style? }\end{array}$ & Inter-grupos & 41,003 & 2 & 4,542 & 0,011 \\
& Intra-grupos & 2040,425 & 452 & & \\
& Total & 2081,429 & 454 & & \\
\hline $\begin{array}{l}\text { 5. Do you constantly use the } \\
\text { reciprocal teaching style? }\end{array}$ & Inter-grupos & 3,1 & 2 & 0,502 & 0,605 \\
& Intra-grupos & 1394,184 & 452 & & \\
& Total & 1397,284 & 454 & & \\
\hline $\begin{array}{l}\text { 6. Do you constantly use the } \\
\text { guided discovered style? }\end{array}$ & Inter-grupos & 83,015 & 2 & 11,511 & 0 \\
& Intra-grupos & 1629,873 & 452 & & \\
& Total & 1712,888 & 454 & & \\
\hline $\begin{array}{l}\text { 8. Do you constantly use the } \\
\text { creative style? }\end{array}$ & Inter-grupos & 112,72 & 2 & 14,316 & 0 \\
& Intra-grupos & 1779,486 & 452 & & \\
\hline
\end{tabular}

The Tukey post-hoc test was performed to gain more in-depth knowledge about what groups revealed these differences (Table 6). Differences were found regarding if 
teachers constantly used the command style, with the teachers who are graduates in physical activity and sport sciences using this style more than teachers who are graduates in physical education (item $3 ; \mathrm{p}=.008$ ).

In addition, differences were observed between teachers who are graduates in physical education and graduates in physical activity and sport sciences regarding the guided discovery style $(\mathrm{p}=.000)$, with teachers who are graduates in physical education using this style more often than graduates in physical activity and sport sciences. Also, teachers with both degrees use guided discovery more often than teachers who are only graduates in physical education (item 6; $\mathrm{p}=.018$ ).

Finally, with respect to the free exploration style (item 8), teachers who are graduates in physical education $(\mathrm{p}=.000)$ and teachers with both degrees $(\mathrm{p}=.002)$ use this style more than teachers who are graduates in physical activity and sport sciences.

Table 6

Tukey's post - hoc test in relation to degree

\begin{tabular}{|c|c|c|c|c|c|}
\hline Items & (I) Degree & (J) Degree & $\begin{array}{l}\text { Mean } \\
\text { difference (I-J) }\end{array}$ & $\begin{array}{l}\text { Typical } \\
\text { error }\end{array}$ & Sig. \\
\hline \multirow{6}{*}{$\begin{array}{l}\text { 3. Do you } \\
\text { constantly } \\
\text { use the } \\
\text { command } \\
\text { style? }\end{array}$} & \multirow{2}{*}{$\begin{array}{l}\text { Graduates in } \\
\text { physical education }\end{array}$} & $\begin{array}{l}\text { Physical activity and sport } \\
\text { sciences graduates }\end{array}$ & $-.783 *$ & 0.26 & 0.008 \\
\hline & & Both degrees & -0.283 & 0.229 & 0.435 \\
\hline & \multirow{2}{*}{$\begin{array}{l}\text { Physical activity and } \\
\text { sport sciences } \\
\text { graduates }\end{array}$} & $\begin{array}{l}\text { Graduates in physical } \\
\text { education }\end{array}$ & $.783 *$ & 0.26 & 0.008 \\
\hline & & Both degrees & 0.501 & 0.281 & 0.176 \\
\hline & \multirow{2}{*}{ Both degrees } & $\begin{array}{l}\text { Graduates in physical } \\
\text { education }\end{array}$ & 0.283 & 0.229 & 0.435 \\
\hline & & $\begin{array}{l}\text { Physical activity and sport } \\
\text { sciences graduates }\end{array}$ & -0.501 & 0.281 & 0.176 \\
\hline \multirow{7}{*}{$\begin{array}{l}\text { 5. Do you } \\
\text { constantly } \\
\text { use the } \\
\text { reciprocal } \\
\text { teaching } \\
\text { style? }\end{array}$} & \multirow{2}{*}{$\begin{array}{l}\text { Graduates in } \\
\text { physical education }\end{array}$} & $\begin{array}{l}\text { Physical activity and sport } \\
\text { sciences graduates }\end{array}$ & -0.191 & 0.215 & 0.648 \\
\hline & & Both degrees & -0.141 & 0.19 & 0.736 \\
\hline & \multirow{2}{*}{$\begin{array}{l}\text { Physical activity and } \\
\text { sport sciences } \\
\text { graduates }\end{array}$} & $\begin{array}{l}\text { Graduates in physical } \\
\text { education }\end{array}$ & 0.191 & 0.215 & 0.648 \\
\hline & & Both degrees & 0.05 & 0.232 & 0.975 \\
\hline & \multirow{3}{*}{ Both degrees } & $\begin{array}{l}\text { Graduates in physical } \\
\text { education }\end{array}$ & 0.141 & 0.19 & 0.736 \\
\hline & & $\begin{array}{l}\text { Physical activity and sport } \\
\text { sciences graduates }\end{array}$ & & & \\
\hline & & & -0.05 & 0.232 & 0.975 \\
\hline \multirow{6}{*}{$\begin{array}{l}\text { 6. Do you } \\
\text { constantly } \\
\text { use the } \\
\text { guided } \\
\text { discovered } \\
\text { style? }\end{array}$} & \multirow{2}{*}{$\begin{array}{l}\text { Graduates in } \\
\text { physical education }\end{array}$} & $\begin{array}{l}\text { Physical activity and sport } \\
\text { sciences graduates }\end{array}$ & $1.112 *$ & 0.233 & 0 \\
\hline & & Both degrees & 0.426 & 0.205 & 0.095 \\
\hline & \multirow{2}{*}{$\begin{array}{l}\text { Physical activity and } \\
\text { sport sciences } \\
\text { graduates }\end{array}$} & $\begin{array}{l}\text { Graduates in physical } \\
\text { education }\end{array}$ & $-1.112 *$ & 0.233 & 0 \\
\hline & & Both degrees & $-.686 *$ & 0.251 & 0.018 \\
\hline & \multirow{2}{*}{ Both degrees } & $\begin{array}{l}\text { Graduates in physical } \\
\text { education }\end{array}$ & -0.426 & 0.205 & 0.095 \\
\hline & & $\begin{array}{l}\text { Physical activity and sport } \\
\text { sciences graduates }\end{array}$ & $.686^{*}$ & 0.251 & 0.018 \\
\hline 8. Do you & Graduates in & Physical activity and sport & $1.301^{*}$ & 0.243 & 0 \\
\hline
\end{tabular}




\begin{tabular}{|c|c|c|c|c|c|}
\hline \multirow{6}{*}{$\begin{array}{l}\text { constantly } \\
\text { use the } \\
\text { creative } \\
\text { style? }\end{array}$} & \multirow[t]{2}{*}{ physical education } & \multicolumn{4}{|l|}{ sciences graduates } \\
\hline & & Both degrees & 0.419 & 0.214 & 0.125 \\
\hline & \multirow{2}{*}{$\begin{array}{l}\text { Physical activity and } \\
\text { sport sciences } \\
\text { graduates }\end{array}$} & $\begin{array}{l}\text { Graduates in physical } \\
\text { education }\end{array}$ & $-1.301 *$ & 0.243 & 0 \\
\hline & & Both degrees & $-.882 *$ & 0.262 & 0.002 \\
\hline & \multirow{2}{*}{ Both degrees } & $\begin{array}{l}\text { Graduates in physical } \\
\text { education }\end{array}$ & -0.419 & 0.214 & 0.125 \\
\hline & & $\begin{array}{l}\text { Physical activity and sport } \\
\text { sciences graduates }\end{array}$ & $.882 *$ & 0.262 & 0.002 \\
\hline
\end{tabular}

* The difference of means is significant at .05.

\section{DISCUSSION}

Regarding if physical education teachers knew teaching styles when they started to work, this research show that teachers who have both degrees (degree in Physical Education and graduates in physical activity and sport sciences), have more knowledge about teaching styles in this first time. The same way, teachers with both degrees are the ones who had had courses in the previous year about teaching styles in physical education in comparison with teachers who are graduates in physical education. Some researches claim that students finish their initial education and they feel insecure. It is for this reason that students have to learn through practice, that is "learning by doing" (Johannes, Fendler and Seidel, 2013).

In addition, the use of different teaching styles depends on the degree. Thus, teachers who are graduates in physical activity and sport sciences use the command style more often than teachers who are graduates in physical education. These results coincide with the research by Cothran et al. (2005), who carried out a study in different countries, observing that one of the most used styles is the command style. Similarly, Jaakkola and Watt (2011) and Hewitt and Kenneth (2013), through their research in different schools in Finland and Australia respectively, concluded that one of the more commonly used teaching styles is the command style. In addition, Boyce (1992) and Derri and Pachta (2007), in their research, observed a greater use of the command style because this style makes it easier to improve the skills which are worked on and learned in physical education classes, as well as improving the retention of such learning.

In addition, the results about if teachers constantly used task assignment, the same style as Mosston's practice style (1986), show that teachers who have both degrees used this style more often than teachers who are graduates in physical education. These results reflect the findings obtained in the research by Curtner - Smith et al. (2001) and Cothran et al. (2005), who say that, other than the command style, the practice style is another teaching style more used because it is the most effective for learning sports skills. Thus, Jaakkola and Watt (2011) and Hewitt, Kenneth (2013) state that, although the command style is one of the styles used more often, physical education teachers also often use the practice style. In addition, Boyce (1992) in his research claims that the task assignment style is used because it helps to improve the learning and retention of students in physical education. In contrast, Brya, Sánchez and Wallhead (2014), claim that although 
practice ando command style are used, students prefer used the inclusion style, because it allows more autonomy and improves their motivation.

Regarding styles that favour students cognitively, this research shows that the use of the guided discovery style depends on the degree held by the teacher. Thus, this style is used more often by teachers who are graduates in physical education and teachers with both degrees than teachers who are graduates in physical activity and sport sciences. Similarly, with respect to the problem solving style, results show that teachers who are graduates in physical education and teachers with both degrees used this style more compared with teachers who are graduates in physical activity and sport sciences. In the research of Medina and Viciana (1996) and Delgado (1998) it is possible to observe that styles which cognitively favour the student are the ones most often chosen by physical education teachers. In addition, Pithers (2002) claim in his research that cognitive learning allows a major individual learning, and therefore students find great satisfaction in their learning and attitudes in classes. This preference about styles which cognitively favour the students, according to the results of research by Morgan, Kingston, and Sproule (2005) and Derri and Pachta (2007), is due to enabling better retention of knowledge as well as improving the class atmosphere and motivation.

Finally, regarding the free exploration style, it is revealed that teachers with both degrees and teachers who are graduates in physical education used this style more often than teachers who are graduates in physical activity and sport sciences. In the same way, Delgado, Medina and Viciana (1996) and Delgado (1998) show in their research that the creative styles are included as one of the five styles preferred by physical education teachers, which could be because creativity is associated with intelligence (Andiliou and Murphy, 2010).

In others styles which are analyzed, it do not find significant different regarding physical education teachers' degrees. Nevertheless, there are researches which show that teaching style such as reciprocal and the self-check styles improve the learning in students (Kolovelonis, Goudas and Gerodimos, 2011).

To summarise, teaching styles are important for giving physical education classes, because they influence learning and motivation in the students (Morgan et al, 2005 and Salvara, Jess, Abbott and Bognar, 2006), as well as academic achievement (Isaza and Henao, 2012). Despite this, teachers prefer to use various teaching styles in the same physical education class, because this facilitates the achievement of objectives (Cothran et al., 2005). Teachers should encourage students to get involved cognitively in their learning, and in this way to increase their learning potential and favour a comprehensive education and motivation (Goudini, Ashrafpoornavaee, and Farsi, 2019; Smith, 2000).

\section{CONCLUSIONS}

Thus, it concluded that the knowledge about teaching styles in physical education, the realization of course year about them, and what teaching styles used more often depend on the degree. 
It can be because of contents teach in different degrees and therefore, how teachers are prepared to give a class.

For this reason, it should research about the knowledge of physical education teachers about different methodologies when they finish their degree.

Thus, it is important to keep in mind that the use of productive styles has a positive influence on the students' learning, and continuous education is essential for being able to use them.

\section{REFERENCES}

Amado, D., Sanchez-Miguel, P. A., Gonzalez-Ponce, I., Pulido-Gonzalez, J. J., \& Del Villar, F. (2016). Motivation towards dance within physical education according to teaching technique and gender. South African Journal for Research in Sport, Physical Education and Recreation, 38(2), 1-16.

Anguera, M. T. (1978). Metodología de la observación en las ciencias humanas. Madrid: Catedra.

Boyce, B. A. (1992). The effects of three styles of teaching on university students' motor performance. Journal of Teaching in physical Education, 11(4), 389-401.

Byra, M. (2000). A review of spectrum research: The contributions of two eras. Quest, 52(3), 229-245.

Byra, M., Sanchez, B., \& Wallhead, T. (2014). Behaviors of students and teachers in the command, practice, and inclusion styles of teaching: Instruction, feedback, and activity level. European Physical Education Review, 20(1), 3-19.

Comunidad de Madrid (2014). Guía de centros docentes de la Comunidad de Madrid. In web: www.madrid.org/centros_docentes/guia/index.html

Cothran, D. J., Kulinna, Kulinna, P. H., Banville, D., Choi, E., Amade-Escot, C., MacPhail, A, Macdonald, D., Richard J.F., Sarmento, P. and Kirk, D. (2005). A CrossCultural Investigation of the use of Teaching Styles. Research Quarterly for Exercise and Sport 76 (2), 193-201.

Cuellar-Moreno, M., \& Caballero-Juliá, D. (2019). Student perceptions regarding the command and problem solving teaching styles in the dance teaching and learning process. Research in Dance Education, 20(3), 297-310.

Curtner-Smith, M. D., Todorovich, J. R., McCaughtry, N. A., \& Lacon, S. A. (2001). Urban teachersi use of productive and reproductive teaching styles within the confines of the national curriculum for physical education. European Physical Education Review, 7(2), 177-190.

Cea D'Ancona, M. A (2001). Metodología Cuantitativa. Estrategias y técnicas de investigación social. (3rd ed.). Madrid: Síntesis. 
Cea D'Ancona, M. A (2004). Métodos de la encuesta. Teoría y práctica, errores y mejora. Madrid: Síntesis.

Delgado, M. A. (1991). Los estilos de enseñanza en la educación fisica. Propuesta para una reforma de la enseñanza. Granada, España: ICE Universidad de Granada.

Delgado, M. A. (1998). Comparación de la valoración de los estilos de enseñanza por los futuros profesores de Educación Física durante la formación inicial y profesores de Educación Física en formación. Educación Física Y Deportes, 3(12).

Delgado, M. A., Medina, J., \& Viciana, J. (1996, November). The teaching styles in the pre-service of physical education teachers. In Internacional Seminar of AIESEP (pp. 2124).

Derri, V., \& Pachta, M. (2007). Motor skills and concepts acquisition and retention: a comparison between two styles of teaching. RICYDE. Revista Internacional de Ciencias del Deporte, 3(9), 37-47.

Goudini, R., Ashrafpoornavaee, S., \& Farsi, A. (2019). The effects of self-controlled and instructor-controlled feedback on motor learning and intrinsic motivation among novice adolescent taekwondo players. Acta Gymnica, 49(1), 33-39. In web: https://gymnica.upol.cz/pdfs/gym/2019/01/05.pdf

Guedea Delgado, J. C. (2010). Análisis de los Estilos de Enseñanza utilizados por los profesores de Educación Física del nivel primaria en la ciudad de Chihuahua. Granada: Universidad de Granada.

de las Heras-Fernández, R., Espada-Mateos, M., \& Cuellar-Moreno, M. J. (2019). Percepciones de los/as estudiantes en los estilos de enseñanza comando y resolución de problemas en el aprendizaje del baile flamenco. Revista Prisma Social, (25), 84-102.

Johannes, C., Fendler, J., \& Seidel, T. (2013). Teachers' perceptions of the learning environment and their knowledge base in a training program for novice university teachers. International journal for academic development, 18(2), 152-165.

Goodyear, V., \& Dudley, D. (2015). "I'ma facilitator of learning!" Understanding what teachers and students do within student-centered physical education models. Quest, 67(3), 274-289.

Goldberger, M., Ashworth, S., \& Byra, M. (2012). Spectrum of teaching styles retrospective 2012. Quest, 64(4), 268-282.

González Tirados, R. M. (2009). Documentos para la docencia. Bases conceptuales en el proceso de la investigación. Madrid: ICE Universidad Politécnica de Madrid.

Valencia, L. I., \& López, G. C. H. (2012). Actitudes-Estilos de enseñanza: Su relación con el rendimiento académico. International Journal of Psychological Research, 5(1), 133-141. 
Jaakkola, T., \& Watt, A. (2011). Finnish physical education teachers' self-reported use and perceptions of Mosston and Ashworth's teaching styles. Journal of Teaching in Physical Education, 30(3), 248-262.

Khalaf, B. K. (2018). Traditional and Inquiry-Based Learning Pedagogy: A Systematic Critical Review. International Journal of Instruction, 11(4), 545-564.

Kolovelonis, A., Goudas, M., \& Gerodimos, V. (2011). The effects of the reciprocal and the self-check styles on pupils' performance in primary physical education. European Physical Education Review, 17(1), 35-50.

Merino-Barrero, J. A., Valero-Valenzuela, A., \& Moreno-Murcia, J. A. (2017). Análisis psicométrico del cuestionario estilos de enseñanza en educación física (EEEF). Revista Internacional de Medicina y Ciencias de la Actividad Física $y$ del Deporte/International Journal of Medicine and Science of Physical Activity and Sport, 17(66), 225-241.

Morgan, K., Kingston, K., \& Sproule, J. (2005). Effects of different teaching styles on the teacher behaviours that influence motivational climate and pupils' motivation in physical education. European physical education review, 11(3), 257-285.

Mosston, M. (1978). Enseñanza de la educación física. Del comando al descubrimiento. Barcelona, España: Paidós.

Mosston, M., \& Ashworth, S. (2002). Teaching Physical Education. 5th ed. London: Benjamin

Patinanoglou, S., Digelidis, N., \& Tsigilis, N. (2008). The command and self-check styles for more effective teaching of tennis at the elementary school. International Journal of Physical Educution, 45, 26-32.

Pithers, R. T. (2002). Cognitive Learning Style: a review of the field dependent-field independent approach. Journal of Vocational Education \& Training, 54(1), 117-32.

Rodríguez Osuna, J. (2002). El análisis de la realidad social. Métodos y técnicas de investigación ( $3^{\mathrm{a}}$ ed.). Madrid: Alianza Editorial.

Salvara, M. I., Jess, M., Abbott, A., \& Bognár, J. (2006). A preliminary study to investigate the influence of different teaching styles on pupils' goal orientations in physical education. European Physical Education Review, 12(1), 51-74.

Sanchez, B., Byra, M., \& Wallhead, T. L. (2012). Students' perceptions of the command, practice, and inclusion styles of teaching. Physical Education \& Sport Pedagogy, 17(3), 317-330.

Sierra Bravo, R. (2001). Técnicas de investigación social. Teoría y ejercicios. Madrid: Thomson.

Smith, F. (2000). Attitudes, learning styles and the workplace. Journal of Vocational Education and Training, 52(2), 281-293. 
Tirados, R.M. (2009). Documentos para la docencia. Bases conceptuales en el proceso de la investigación. Madrid: ICE Universidad Politécnica de Madrid.

Wallhead, T. L., Garn, A. C., \& Vidoni, C. (2014). Effect of a sport education program on motivation for physical education and leisure-time physical activity. Research quarterly for exercise and sport, 85(4), 478-487.

Zeng, H. Z., Leung, R. W., Liu, W., \& Bian, W. (2009). Learning outcomes taught by three teaching styles in college fundamental volleyball classes. Clinical Kinesiology (Online), 63(1), 1. 